\author{
Marquette University \\ e-Publications@Marquette
}

College of Education Faculty Research and

Publications

Education, College of

3-2008

\title{
Case Studies of the Attainment of Insight in Dream Sessions: Replication and Extension
}

\author{
Sarah Knox \\ Marquette University, sarah.knox@marquette.edu \\ Clara E. Hill \\ University of Maryland \\ Shirley A. Hess \\ Shippensburg University of Pennsylvania \\ Rachel E. Crook-Lyon \\ Brigham Young University
}

Follow this and additional works at: https://epublications.marquette.edu/edu_fac

Part of the Clinical Psychology Commons, and the Education Commons

\section{Recommended Citation}

Knox, Sarah; Hill, Clara E.; Hess, Shirley A.; and Crook-Lyon, Rachel E., "Case Studies of the Attainment of Insight in Dream Sessions: Replication and Extension" (2008). College of Education Faculty Research and Publications. 27.

https://epublications.marquette.edu/edu_fac/27 


\title{
Case Studies of the Attainment of Insight in Dream Sessions: Replication and Extension
}

\author{
Sarah Knox ${ }^{1}$ \\ Department of Counseling and Educational Psychology, School of \\ Education, Marquette University \\ Milwaukee, WI \\ Clara E. Hill² \\ Department of Psychology, University of Maryland \\ College Park, MD \\ Shirley A. Hess ${ }^{3}$ \\ Department of Counseling and College Student Personnel, \\ Shippensburg University \\ Shippensburg, PA \\ Rachel E. Crook-Lyon ${ }^{4}$ \\ Department of Counseling Psychology and Special Education, \\ School of Education, Brigham Young University \\ Provo, UT
}

\begin{abstract}
To replicate and extend the Hill, Knox, et al. (2007) case study of a client who attained insight in one session of dream work, the authors examined two additional single-session cases: one in which a client gained insight and another in which a client did not. The observations across all three cases suggest that the two clients who acquired insight had positive attitudes toward dreams; were motivated and involved in session; and were
\end{abstract}


nonresistant, trusting, and affectively present but not overwhelmed. The client who did not gain insight questioned the value of dreams and was resistant, untrusting, and emotionally overwhelmed. Therapist adherence and competence using the dream model, ability to manage counter-transference, and effective use of probes for insight distinguished the therapists whose clients gained insight from the therapist whose client did not.

According to Frank and Frank (1991), the human need to make sense of events-to achieve insight-is as fundamental as the need for food and water. This need may be especially true for therapy clients, many of whom seek insight, which can be defined as follows:

A client's expressing an understanding of something about him/herself and articulating patterns or reasons for behaviors, thoughts, or feelings; insight usually involves an "aha" experience in which the client perceives self or world in a new way; in addition, with insight the client takes appropriate responsibility rather than blaming others, using "shoulds" imposed from the outside world, or rationalizing. (Hill et al., 1992, pp. 548-549)

Insight is, in fact, central to many approaches to psychotherapy. Psychoanalytically and psychodynamically oriented therapists perhaps most obviously (see Messer \& McWilliams, 2006) consider insight a key component of their work, but insight is important in experiential (Pascual-Leone \& Greenberg, 2006) and cognitive-behavioral (Holtforth et al., 2006) orientations as well. Regardless of theoretical orientation, then, insight likely plays a vital role in psychotherapy, and its acquisition may be a motivation for clients entering psychotherapy. Although research suggests that clients do develop insight, both during and as a result of therapy, there is little consistent evidence regarding how insight is actually achieved (Hill \& Knox, 2007). Thus, a primary purpose of the current study was to learn more about how clients achieve insight.

One therapeutic venue for examining insight attainment may be through dream work, because clients often present dreams they seek to understand. We focus here on Hill's integrative model (1996, 2004a) of dream work for two reasons: Insight is a primary goal of this three-stage model (i.e., exploration, insight, action) that integrates client-centered, psychoanalytic, gestalt, and behavioral theories; and the model has received more empirical attention than 
any other dream model (see reviews by Eudell-Simmons \& Hilsenroth, 2005; Hill \& Goates, 2004; Pesant \& Zadra, 2004). Hill and Goates (2004) cited three sources of evidence that clients gain insight: (a) Clients have reported on postsession measures that they gained insight, (b) judges rated clients' levels of insight in written dream interpretations as higher after dream sessions than before, and (c) clients identified gaining awareness or insight as the most helpful component of dream sessions. Relatedly, Hill et al. (2006) found that clients who gained insight into dreams had low initial levels of dream insight, were very involved in the exploration and insight stages, and had therapists who adhered to and were competent with the model.

Thus, in an effort to further illuminate how insight develops, Hill, Knox, et al. (2007) took one case (i.e., Shari) from Hill et al.'s (2006) study of 157 single sessions of dream work and examined how insight was achieved. The findings suggested that dream salience, the therapeutic relationship, client variables (i.e., readiness, involvement), and therapist variables (i.e., adherence to and competence with the model, minimal countertransference, probes for insight) were associated with insight acquisition. Furthermore, there was evidence that client factors (i.e., flat affect, lack of psychological mindedness, anxiety) and therapist factors (i.e., overidentification with the client) impeded insight.

The current study used a similar case study methodology to replicate and extend Hill et al.'s (2007) observations of how insight developed through dream work. One element involved replication, an approach used to test the generalizability of observations (Hilliard, 1993). Thus, we hoped to determine, by examining a new case similar to that in Hill et al. (i.e., the present case also demonstrated gains in judge-rated insight from presession to follow-up and was judged a successful session), whether factors associated with insight in the earlier study would also emerge here. By extension (a purpose not mutually exclusive from replication), we examined a new case in which insight declined and the target problem worsened at follow-up to assess whether this decline corresponded with lower levels of factors previously associated with insight gains or whether there may be other factors impeding insight achievement. Following the Hill et al. (2007) case study, we postulated that dream salience, the therapeutic 
relationship, client variables (readiness, involvement), and therapist variables (adherence to and competence with the model, minimal countertransference, probes for insight) would be associated with insight acquisition. Furthermore, we postulated that client (flat affect, lack of psychological mindedness, anxiety) and therapist (overidentification with the client) factors would impede insight gains.

Case studies have a long history in psychotherapy research because they enable researchers to explore phenomena (e.g., insight acquisition) in one individual in the hope that such exploration illuminates how the phenomena operate more broadly (Heppner, Kivlighan, \& Wampold, 1999). In focusing on extreme rather than representative examples (Stiles, 2003), case studies offer an alternative research strategy to statistical hypothesis testing by fostering investigation of the subtlety and complexity of psychotherapy (Stiles, 2005). This methodology also allows for triangulation (Kazdin, 1981; Yin, 1994), or using evidence from a number of different sources. Hence, we collected quantitative data from the client, therapist, and an observer and used a qualitative approach of relying on consensus among judges to evaluate nonquantitative data.

This study involved single sessions with volunteer clients in a laboratory setting to study insight attainment in dreams, which allowed us to better test the questions of interest. With single sessions, few confounding variables from additional sessions or the outside world impinge. Thus, if clients gain insight during the session, we can more readily connect such gains to something that occurred within the session. We also assert that a single session of dream work can be a therapeutic intervention in its own right, in that research has shown that clients gain insight and make changes on target problems after such sessions (Eudell-Simmons \& Hilsenroth, 2005; Hill \& Goates, 2004). Because everyone dreams and some dreams are distressing, understanding how people gain insight may yield insights into the meaning of the dream itself as well as helpful understandings for waking life. Finally, using volunteer clients assures us of having participants who want to work on dreams and do not need to work on other things more pressingly, as is often the case in ongoing therapy.

Psychotherapy Research, Vol. 18, No. 2 (March 2008): pg. 200-215. DOI. This article is (C) Taylor \& Francis (Routledge) and permission has been granted for this version to appear in e-Publications@Marquette. Taylor \& Francis (Routledge) does not grant permission for this article to be further copied/distributed or hosted elsewhere without the express permission from Taylor \& Francis (Routledge). 
NOT THE PUBLISHED VERSION; this is the author's final, peer-reviewed manuscript. The published version may be accessed by following the link in the citation at the bottom of the page.

\section{Method}

\section{Archival Data}

In Hill et al. (2006), 42 trained therapists conducted 157 sessions with volunteer clients. Relevant details about the procedures for the larger study, from which the current cases were drawn, are presented here briefly to provide context.

\section{Recruiting Client}

Volunteer clients were recruited on three university campuses. Potential clients were informed that they must be willing to discuss a dream with a trained therapist and could not currently be in psychotherapy. No restrictions were placed on who participated (i.e., students seeking or not seeking course credit, nonstudents). Clients were asked to bring a written copy of their dream to the session.

\section{Sessions}

Volunteer clients first signed a consent form. Using the written copy of their dream, they rated the dream salience (Hill et al., 2006) and wrote an interpretation. They also completed the Attitudes Toward Dreams-Revised (Hill et al., 2001) and a demographic form. All measures were completed in random order.

In audiotaped sessions, the therapist provided an overview of the dream model, asked the client to tell the dream, and facilitated the exploration stage (asking for description, reexperiencing, associations, and waking-life triggers for several images). At the end of this stage, the therapist stopped the session, and both the therapist and the client independently rated therapist competence and client involvement. For the assessment of insight after the exploration stage, the therapist asked about the meaning of the dream. The therapist then began the insight stage, helping the client construct the meaning of the dream in terms of waking life, intrapersonal dynamics, or existential or spiritual concerns. For the assessment of insight after the insight stage, the therapist again asked the client about the dream's meaning. The therapist and client again independently rated therapist competence

Psychotherapy Research, Vol. 18, No. 2 (March 2008): pg. 200-215. DOI. This article is (c) Taylor \& Francis (Routledge) and permission has been granted for this version to appear in e-Publications@Marquette. Taylor \& Francis (Routledge) does not grant permission for this article to be further copied/distributed or hosted elsewhere without the express permission from Taylor \& Francis (Routledge). 
and client involvement. Next came the action stage, in which typically the therapist helps the client change the dream and apply these changes to waking life. Finally, the therapist and the client again independently rated therapist competence and client involvement.

Immediately after the session, clients and therapists completed the Relationship Scale and Session Evaluation Scale (Hill \& Kellems, 2002). Clients also rated the underlying Target Problem (Hill et al., 2006) for both how they felt currently and how they retrospectively thought they felt before the session. Two weeks later (follow-up), clients reported how much time per day they spent thinking about their dream since the session and wrote an interpretation of the dream.

Trained judges rated the insight into the presession, postexploration stage, and postinsight stage dream interpretations (Hill et al., 1992). In addition, the four authors coded all therapist interventions using the Helping Skills System (Hill, 2004b) and rated insight (Hill et al., 1992) in every client speaking turn by consensus.

\section{Current Study}

\section{Researchers}

Two European American female assistant professors (53 and 31 years old, respectively) were the primary team for the insight achieved case and auditors for the other case; two European American women (a 43-year-old assistant professor and a 56-year-old professor) were the primary team for the insight not achieved case and auditors for the other case; they were humanistic and psychodynamic in orientation. All valued insight in psychotherapy and knew the study's purposes.

\section{Procedures for Selecting the Two Cases}

We reviewed data for the 157 single sessions of dream work in the archival data set (Hill et al., 2006) and identified cases with the highest and lowest judge-rated insight gains. From this subset of cases, we chose the case with the highest gains and the case with the 
NOT THE PUBLISHED VERSION; this is the author's final, peer-reviewed manuscript. The published version may be accessed by following the link in the citation at the bottom of the page.

lowest gains that were most similar to the Hill et al. (2007) case in terms of age, gender, and lack of previous and current therapy.

\section{Qualitative Analyses}

The primary team for each case independently listened to the audiotape and read the session transcript to familiarize themselves with the case. They next read the transcript together and discussed their reactions. Then they reviewed the session again, identifying evidence (actual words of the session from the transcript or tape) for dream, client, and therapist factors that seemed associated with insight gains. Finally, they reached consensus regarding all evidence.

The two auditors listened to the tape, read the transcript, and indicated their level of agreement or disagreement with each primary team assertion. They also looked for overlooked evidence and offered other interpretations or conclusions. The primary team considered the auditors' comments and modified the manuscript through consensus. This audit/reconsideration process continued until all researchers felt confident in the assertions regarding insight attainment. In all steps of data analysis, the researchers remained open to evidence for new contributors to insight attainment beyond those captured by dream, client, and therapist factors and to new aspects within these three previously identified domains.

\section{Results}

We first describe the process and outcome of each case and document that insight did or did not occur. We then examine the role of dream salience, therapeutic relationship, and client and therapist factors in the acquisition, or lack thereof, of insight. Table I shows the measures for the Hill et al. (2007) case (Shari), the insight achieved (Ingrid) and not achieved (Natalie) cases for the present study, and the entire sample from which cases were drawn (Hill et al., 2006). (All clients names used here are pseudonyms to protect confidentiality.) Client speech was altered slightly (e.g., deleted "you know," "like") to enhance readability in the examples.

Psychotherapy Research, Vol. 18, No. 2 (March 2008): pg. 200-215. DOI. This article is (c) Taylor \& Francis (Routledge) and permission has been granted for this version to appear in e-Publications@Marquette. Taylor \& Francis (Routledge) does not grant permission for this article to be further copied/distributed or hosted elsewhere without the express permission from Taylor \& Francis (Routledge) 
NOT THE PUBLISHED VERSION; this is the author's final, peer-reviewed manuscript. The published version may be accessed by following the link in the citation at the bottom of the page.

\section{Insight Achieved Case}

Ingrid, a 19-year-old European American woman in her freshman year of college, was not nor had ever been in therapy. Ingrid's therapist for the current study was a 25-year-old European American female graduate student in a school psychology master's program. She had two semesters of clinical experience but no experience with dream work. Her theoretical orientation was humanistic and cognitive-behavioral.

The Dream and Initial Client Interpretation

Ingrid presented the following recurrent dream that she had between ages 7 and 12:

I would be walking through some kind of building, which was very light inside. Everything was white and clean, and there were lots of large women on stretchers. I assumed it was a hospital and the ladies were all pregnant. So I would be walking, maybe even running (from something or someone), and I come to part of the dream that was very unpleasant. I would see massive people and furniture, and I was very small in comparison. Everything around me had a lot of mass and density. It seemed like everything was made out of clay-very heavy and packed. I would start to feel very dense, too, and I dreamt that my hands would become dense and clay like. Next I would see a thread or something very thin cutting through the dense objects, and it was very uncomfortable-not that the thread thing was going through me, but it just was uncomfortable to watch it. I would physically become very tense, and I would awake from this dream with my fists balled up. I would try to open my hands because it hurt for them to be so tight, but I would be unable to unclench them.

When asked for an interpretation before the session, Ingrid wrote: "I really have no idea-it was all very obscure. Maybe during that time in my life I was very stressed out or feeling under some kind of burden. My dream was very hard to understand."

Psychotherapy Research, Vol. 18, No. 2 (March 2008): pg. 200-215. DOI. This article is (c) Taylor \& Francis (Routledge) and permission has been granted for this version to appear in e-Publications@Marquette. Taylor \& Francis (Routledge) does not grant permission for this article to be further copied/distributed or hosted elsewhere without the express permission from Taylor \& Francis (Routledge). 
NOT THE PUBLISHED VERSION; this is the author's final, peer-reviewed manuscript. The published version may be accessed by following the link in the citation at the bottom of the page.

\section{Process and Outcome of the Session}

We describe the process of this 80 -min session (45 min exploration, 20 min insight, and 15 min action) so that readers have a context within which to understand our observations.

\section{Process of the Session}

After Ingrid retold the dream, her therapist asked about her feelings in the dream. Ingrid responded, "Well, I would get frightened when I saw the fake clay-like objects because I didn't know what they were and I would feel dense, like I had a lot of mass, but I was very small, in comparison."

The therapist and Ingrid then explored dream images. For example, Ingrid described moving from the light room to a darker place with clay-like objects: "As the dream went on these objects got more mass everything was compacted very tightly, yet they were still movable, so I would see these images, these objects, it was a little dim and everything was gray." The therapist asked, "So, how did you feel when you went into this different place, this darker room?" Ingrid replied,

I got more scared and worried. I don't know if I was worried about, if I was still looking and was worried I wasn't going to find somebody, it was just very unfamiliar, like what these things were by the end of the dream I was pretty stressed I started to feel smaller because everything was just so big, but I maybe I just started feeling more compacted, it was like it was pushing in on me. It's so weird to explain, very hard and heavy inside.

When asked about memories of being dense or heavy, Ingrid responded, "I would get stressed out and frustrated when I didn't understand what was going on around me or when other people were stressed out around me, like somebody's having an argument or something, it would affect me a lot, so, I feel that stress and tightness."

Psychotherapy Research, Vol. 18, No. 2 (March 2008): pg. 200-215. DOI. This article is @ Taylor \& Francis (Routledge) and permission has been granted for this version to appear in e-Publications@ Marquette. Taylor \& Francis (Routledge) does not grant permission for this article to be further copied/distributed or hosted elsewhere without the express permission from Taylor \& Francis (Routledge). 
At the end of the exploration stage, Ingrid's interpretation of the dream was, "I never thought it had any meaning, but I think it must because it was recurring; I've had the dream at least 20 times. But the meaning, I really don't know [laugh]. I maybe felt like really big things were intimidating because I was a small child or scared of fat people or something."

In the insight stage, Ingrid connected the part of herself that was looking for something in the dream to a preoccupation with searching in waking life: "I'm always searching for something, whether it's knowledge, or looking for a person, or looking to the future, looking to the past I'm always thinking about what could happen in the future, what's going to happen now." Ingrid became pensive as she responded to the therapist's question about what part of herself was like going into the dark room where she felt small, dense, and stressed: "When I was younger I was very shy and I felt like I wasn't really noticed. And I remember being frustrated when people wouldn't listen to me because I was so quiet. So when I did say something, I was like 'they should listen."' Ingrid continued:

I was compliant people would tell me to go do this and go do that, and would kind of boss me around. So maybe that was like, maybe people would tease me about being shy or like the string going through [the clay objects] but not really affecting it. It wouldn't change, maybe that was like when people would say things that would make me feel tight inside, but I didn't really want to change.

Ingrid's postinsight stage interpretation was, "I think that it means as a child I felt enclosed within myself a lot because of how other people saw me or because of how I thought other people saw me even when they didn't see me. I didn't like how people saw me. It would make me feel frustrated. Like I'd wake up and I wouldn't be able to unclench [my fists]." In response, the therapist said, "You probably just didn't know how to not be shy and that frustrated you and because you were shy, it didn't come out." This statement moved Ingrid to reflect that,

Once I got to junior high I realized that being shy is not how I wanted to be anymore. I didn't want people to be like, "Oh, she's just a shy girl" and not get to know me better. So, I

Psychotherapy Research, Vol. 18, No. 2 (March 2008): pg. 200-215. DOI. This article is (c) Taylor \& Francis (Routledge) and permission has been granted for this version to appear in e-Publications@ Marquette. Taylor \& Francis (Routledge) does not grant permission for this article to be further copied/distributed or hosted elsewhere without the express permission from Taylor \& Francis (Routledge). 
changed a lot and by high school I was a social butterfly. And, I'm totally different, so, I think the dream stopped, that's about the time I didn't have the dreams anymore, when I didn't want to be [shy] like that.

During the action stage, Ingrid indicated that she would like to be "really friendly with people" and not "worry about what other people think. So, if I could make a change in my life, I would not care what other people think about me. I would try to be myself more and realize that everybody is feeling the same way and everybody is worried about what everybody else thinks." Ingrid also wanted to be more genuine: "When I'm really being sincere with someone, and really being myself, that's when I'm most comfortable."

Ingrid then made a connection to not being able to be herself around her sister: "I feel like I can't be myself around my sister because she puts up false she wants people to think she's something she's really not it's uncomfortable for me to be myself because she's not herself." Ingrid wished to break down the walls between her and her sister, but she was not sure that her sister wanted to try. When the therapist suggested that Ingrid and her sister were adults now and perhaps things could be different, Ingrid reconnected back to the dream: "It's so hard because I feel like she [sister] perceives me as still that little girl. So when I'm around her, I feel the same things I felt in the dream I was frustrated inside and I feel that shy and I'm not myself." In closing this stage, Ingrid asserted that she was "going to try to be more genuine with people I'm going to go out of my comfort zone to be more confident and especially with my sister. We'll both feel comfortable."

\section{Outcome of the Session}

Table I shows that Ingrid gained insight into her dream during the session. She also perceived that she increased in her functioning on the target problem (i.e., "being insecure with my shyness as a child, being frustrated and uncomfortable with the way people perceived $\mathrm{me}^{\prime \prime}$ ) reflected in the dream. 
At the 2-week follow-up, Ingrid reported that she spent 5 to 10 min per day thinking about the dream. Her written interpretation of the dream at this time was as follows:

I interpret the dream as being a representation of my frustration as a child. It represents how unnoticed and insignificant I would feel sometimes when I was with other people. I felt this way because I thought that other people didn't think my feelings or opinions were valid, so they wouldn't pay attention to me. I was very quiet and shy, and I would feel intimidated by adults or other loud people. I interpret the large, dense, clay-like objects as these people who I would feel small and frustrated around.

Compared with postsession, this follow-up interpretation was rated higher on insight, indicating that Ingrid gained insight after the session. She rated her functioning on the target problem at the same level as she had postsession.

\section{Factors Associated With Insight}

\section{Dream Salience}

Before the session, Ingrid rated the dream as moderately salient. She appeared, however, to view it as more salient during the session. For example, early in the session she stated that, "Right now, I don't think it [the dream] has much meaning." Later, however, Ingrid said, "I have never thought it had any meaning, but I think it must because it was recurring." Toward the end of the session, Ingrid stated that the dream "was really interesting."

\section{The Therapeutic Relationship.}

Both Ingrid and her therapist gave high ratings to the therapeutic relationship (see Table I). The therapist's encouragement and support of Ingrid may have contributed to the development of the relationship. For instance, after Ingrid first told the dream, the therapist replied, "Wow! That's awesome." Similarly, the therapist offered reassurance when Ingrid expressed concern about not understanding the dream images by saying, "Well, that's what we're here for." The therapist also instilled hope: "Hopefully after 
everything's done you'll have more insight about what this dream means." Ingrid seemed to have felt listened to by the therapist, a phenomenon contrary to her experience in her dream and in childhood. Often the therapist restated what Ingrid said, asked about feelings, and checked in to make sure she understood Ingrid's perspective. Finally, Ingrid participated actively in every step of the session.

There was, however, some tension in the relationship given their different styles. Ingrid seemed an internal processor, taking her time to absorb the therapist's probes and connections and speaking slowly. By contrast, the therapist occasionally seemed to push the pace.

\section{Client Factors}

Attitude toward dreams. Ingrid's attitude toward dreams was higher than average (see Table I). Hence, Ingrid valued her dreams and believed them to be meaningful.

Readiness/motivation. Ingrid appeared ready and motivated to explore the dream, agreeing with the statement at presession, "I am eager to learn more about what this particular dream means." In session she seemed puzzled by the dream, admitting that it stirred up emotions.

Client involvement. Table I shows that the client saw herself as highly involved in the session, whereas the judges rated Ingrid's involvement as moderate, and the therapist rated Ingrid as not very involved. We observed that Ingrid had difficulty at times providing rich responses and insights, but that her involvement deepened as she became more trusting and more engaged in the process. The disparity between Ingrid's and her therapist's ratings may reflect their different styles (see prior discussion), such that the therapist may have misread Ingrid's deliberate style as low involvement.

Although not a highly emotional session, Ingrid did become reflective and speak with greater feeling as the session progressed. When responding to the therapist's question about how she felt going permission has been granted for this version to appear in e-Publications@Marquette. Taylor \& Francis (Routledge) does not grant permission for this article to be further copied/distributed or hosted elsewhere without the express permission from Taylor \& Francis (Routledge). 
into a dark room, Ingrid's voice slowed and softened: "I got scared and worried. I don't know if I was still looking and that I was worried I wasn't going to find somebody, or it was just very unfamiliar by the end of the dream I was pretty stressed."

Guardedness. Although Ingrid gained substantial insight, her guardedness may have inhibited further acquisition of insight. We inferred guardedness given that Ingrid laughed nervously seven times, typically after exploring a section of the dream that was frightening or confusing. Likewise, she laughed when discussing waking-life situations that felt uncomfortable or when she did not understand what was happening around her (e.g., childhood fear of darkness, frustration at not understanding her older siblings). She was also occasionally distracted, asking the therapist three times to repeat her question. In addition, she repeatedly referred to not understanding aspects of her dream (e.g., objects in the dream were "very unfamiliar") and made several contradictory statements (e.g., she said she was "a happy little kid [laugh]" but later said "I was a scared little $\mathrm{kid}^{\prime \prime}$ ). Finally, Ingrid seemed somewhat reluctant to delve into the dream's meaning, labeling it both "weird" and "psycho."

\section{Therapist Factors}

Adherence and competence. The therapist adhered closely to the model and was thorough in following the treatment protocol. For example, when the therapist began to explore a second image before completing the first image, she said, "I'm actually getting ahead of myself, so let's go back to the buildings." The judges and client rated the therapist as moderately to extremely competent, respectively, although the therapist rated herself as not very competent (see Table I). Given that this was the therapist's first dream session and she had limited clinical experience, perhaps the therapist lacked confidence and judged her skills as inadequate. The client, on the other hand, may have found the therapist's clinical naiveté nonthreatening in a "we're in this together" way. A sign of competence was the therapist's conscientiousness about checking her understanding of Ingrid's statements. For example, when Ingrid described the end of her dream, the therapist clarified by asking, "So you end when you're floating in the air does that sound right?" 
Although the therapist's clinical naiveté may have aided the therapeutic relationship, it may also have hampered the session quality. During the exploration stage, the process stalled when the therapist asked closed questions and cut off the client's exploration. Thus, the therapist's close (and perhaps rigid) adherence to the model may have inhibited the session flow such that opportunities for exploration, follow-up, and potential insight gains were missed.

Countertransference. At postsession, the therapist wrote, "I felt kind of like a big sister. I perhaps was too big-sisterly instead of clienttherapist." In addition, she indicated that her own unresolved needs, conflicts, or feelings were "slightly" evoked by Ingrid (e.g., she identified with Ingrid's struggles with shyness). We speculate that this sisterly countertransference manifested in the therapist becoming directive in the action stage, but posit that it may have facilitated insight by focusing on Ingrid's feelings about her sister. We also speculate that Ingrid benefited from being heard by an older woman, perhaps a projection of a big sister, during the session.

Therapist skills. Probes for insight were consistently associated with immediate client insight. When the therapist asked Ingrid what part of her was similar to "going into the dark room and feeling small and dense and stressed?" Ingrid replied, "When I was younger, I was very shy and I felt like I wasn't noticed a lot. I remember being frustrated when people wouldn't listen to me because I was so quiet. So when I did say something, I was like 'they should listen."' Directly asking about the meaning of the image prompted Ingrid to connect it to a childhood experience.

In addition, interpretations were associated with client insight (although there were only four). In one example, after the therapist inquired about her feeling dense in the dream, Ingrid responded that she felt frustrated as a child when people did not listen to her because she was so quiet. The therapist connected Ingrid's shyness with density in a mild interpretation: "You're feeling shy, you're feeling small, and you're feeling frustrated that people don't listen and you felt really affected if people would fight-maybe that could be a part of feeling the density." Ingrid responded, "I think it was more stress because I wasn't comfortable being shy, not being able to express how permission has been granted for this version to appear in e-Publications@Marquette. Taylor \& Francis (Routledge) does not grant permission for this article to be further copied/distributed or hosted elsewhere without the express permission from Taylor \& Francis (Routledge). 
I felt. It's always frustrating when people don't listen to you. I think that's why I was feeling so tight inside. I felt like I wanted to just relax." Hence, this interpretation, delivered gently and close to the surface, allowed Ingrid to continue thinking about the meaning of the dream.

\section{Summary of Insight Achieved Case}

Ingrid's dream was salient, she viewed it as interesting and perplexing, and the strong therapeutic relationship set the foundation for exploration. Her positive attitudes toward dreams facilitated her work in the session, and she was cooperative and involved. The therapist adhered to the model, was relatively competent, had benign and possibly facilitative countertransference, and used good therapeutic skills (probes for insight and interpretation). However, Ingrid was somewhat guarded (e.g., nervous laughter, contradictions, reluctance), and the therapist was inexperienced and a bit clumsy using the model and was perhaps too directive in the action stage. In our judgment, the facilitating factors outweighed the hindering factors, so that insight could be attained.

\section{Insight Not Achieved Case}

Natalie was a 22-year-old African American woman in her junior year of college. She was not, nor had she ever been, in psychotherapy. Natalie's therapist for this session was a 24-year-old European American female graduate student in a counseling psychology doctoral program. She had two semesters of clinical experience and $6 \mathrm{hr}$ of training in the Hill dream model. She rated herself as humanistic, cognitive-behavioral, and psychodynamic.

\section{The Dream and Initial Client Interpretation}

Before her session, Natalie wrote about a recurrent dream that she had twice a week between ages 7 and 14 and then had again approximately 3 years ago:

I was on some kind of beach looking down. I knew that I had a purpose and goal in the dream, but I did not know why. I was 
like an hourglass with a hole in the bottom. Sand would come out of the bottom but not in the form of sand. It would be in the form of an indented line. The line looked as if it was drawn with the front tip of a shoe. I was responsible for keeping an invisible straight line through the sand. If the line ever deviated from the path, I would become angry with myself and immediately try to fix it. The colors in the dream were always tan and orange, like a sunset, but I was never able to look up, nor did I want to. The deviation from the line was caused by my lack of concentration.

Natalie initially wrote this interpretation: "I think that the dream has something to do with being a perfectionist. I must have control over my life and if I don't, I am easily frustrated. I am not sure if I believe this. Since the dream is so basic I could only imag(ine) that it is not that important."

\section{Process and Outcome of the Session}

As in the prior case, we describe the process of this 80 -min session (45 min exploration, 15 min insight, 20 min action) to provide readers with a context for our observations.

\section{Process of the Session}

After retelling her dream, Natalie said that she felt,

Nothing, I really don't have any feelings. The only emotions I definitely know I feel is when the line moves or I will mess it up, and I'm completely frustrated and upset, and I have to get it straight, and it's almost a feeling of like not disgust in the way that you would think I'm disgusted with myself because I didn't get the line moving I feel kinda sick.

The therapist then asked Natalie to explore the images of the dream. Of her body as an hourglass, Natalie said, "I didn't see myself as an hourglass but I knew I was. And there was sand coming out of the bottom and usually it's like a lump over the top of the sand, but it didn't come out like that. It would come out as a dent, but it was normal to me in the dream ...I didn't have a body ...it was like my eyes or something, just vision." When the therapist asked how it felt not to have a body, Natalie said that she was not surprised and that

Psychotherapy Research, Vol. 18, No. 2 (March 2008): pg. 200-215. DOI. This article is (c) Taylor \& Francis (Routledge) and permission has been granted for this version to appear in e-Publications@Marquette. Taylor \& Francis (Routledge) does not grant permission for this article to be further copied/distributed or hosted elsewhere without the express permission from Taylor \& Francis (Routledge). 
having an hourglass as a body felt normal. As the hourglass dispensing the sand, however, Natalie reaffirmed her duty to keep the line straight, stated that frustration emerged only when the line wasn't straight and that "I would have to make it go straight in order to be at peace." In her associations to the hourglass, Natalie responded, "Well, time ...didn't say my supply of time was limited in the hourglass of my dreams, but time and that's it." As a waking-life trigger, Natalie recalled a childhood game with an hourglass and her fascination with its sand. Natalie also remembered that she loved her mother's wooden hourglass, wanting to cut it open and take out the sand. Soon after making the association between the hourglass and her mother, Natalie cried, explaining that her parents divorced near the time she had the dream as a child. She didn't understand why she was crying because her parents had been long divorced ("it's not a big deal to me now"). After the exploration stage, Natalie's interpretation was,

I don't know. All I can think about is that I really liked the hourglass. But at the time, to have a dream about perfectionism and like keeping on a straight path, I wouldn't think that I'd be able to understand what that means. I'm very interested in dream interpretation but I don't really see how Maybe at the time keeping a straight line meant keeping all my family together but I had the dream before that. So, I can't imagine I loved that hourglass and I loved going to the beach with my family.

In the insight stage, Natalie said that she worried a lot, that she was concerned about other people's feelings ("I'm always concerned about what people think of me, what I should do, it's almost sickening to the point that I'm gonna hit the bottom of my stomach I'm gonna actually get sick"). She also acknowledged that she experiences "a panic mode" in response to "the slightest things you couldn't even imagine" regarding those she loves (e.g., when friends come home late, she wonders if they were in an accident). She wanted to stop this worrying and wanted not to take on "other people's issues or care so much about what everybody else thinks of me."

Natalie connected the hourglass to frustration, happiness, and control, which she then associated with the change in schools she made when her parents divorced ("'before the move] I was used to all the same kids because I was going from grade to grade and I wasn't permission has been granted for this version to appear in e-Publications@Marquette. Taylor \& Francis (Routledge) does not grant permission for this article to be further copied/distributed or hosted elsewhere without the express permission from Taylor \& Francis (Routledge). 
fearful of the next year because I knew everybody from the last year"). This need for control, according to Natalie, also emerged in her "duty" to keep the line straight in the dream ("I had to keep a straight line I like taking on responsibility cause I don't really trust other people to do it I have to know what's going on") Finally, Natalie speculated that she started thinking about being in control at the same time as she had the dream, which coincided with her parents' divorce. After this stage, Natalie's interpretation was,

I wouldn't know. I just think it has to do with ...the way I think ...started thinking this way when I was around that age [of the dream]. Being in control ...being really focused or attempting to be focused ...I'm so sick of always being concerned about everyone else. I'm always concerned about how other people think of me. What should I do? Just upsetting, and I wish I could stop it. But they just keep coming through; it's always a burden for me.

In the action stage, Natalie stated that she would change the part of her dream where "the line starts moving off, out of the way ...because [of] the feeling that I get when it did mess up." Such a change would mean that there would be "pretty much no feelings during the whole dream." Natalie indicated that translating this change into real life "would be unrealistic. I wish I didn't feel so pressured to have everything or pressures that I don't even think I should be feeling." To make these changes, Natalie wanted to stop trying to control everything, trying to put all the pressure on herself, worrying so much before she developed an ulcer, and caring so much about what other people think. Natalie then abruptly shifted topics and stated that as a spiritual person who believed in God and was "supposed to not have these feelings," she needed to release them to God and become more spiritually involved (i.e., read the Bible, go to church). She further said that if she had faith, she "wouldn't be worried about stuff like that." During this stage, the therapist recommended repeatedly that Natalie go to the counseling center for help. Natalie rejected these suggestions, stating that her faith was a more appropriate source for working through her difficulties. 
NOT THE PUBLISHED VERSION; this is the author's final, peer-reviewed manuscript. The published version may be accessed by following the link in the citation at the bottom of the page.

\section{Outcome of the Session}

As Table I shows, Natalie was rated as having moderate insight in her initial dream interpretation and after the exploration stage, but she declined in insight after the insight stage. With the target problem reflected in her dream ("control of my emotions"), Natalie rated her functioning as moderate both before and after the session. We conclude that the session yielded few, if any, salutary effects on Natalie's insight development or her target problem functioning.

At the 2-week follow-up, Natalie reported that she had not thought at all about the meaning of her dream since the session. Her written interpretation at follow-up (rated as lower in insight than the pre-and postsession interpretations) was "I still very much believe that it was a vague dream about a trip I had to the beach. I really don't think that it was too deep psychologically. I think that the dream was important because it allowed me to release emotions that I had not thought about in a long time." Likewise, Natalie rated her functioning on the target problem at follow-up as even lower than she had after the session.

\section{Factors Associated With Insight}

\section{Dream Salience}

Although Natalie's Dream Salience score was moderate (see Table I), she stated both before the session and at the 2-week followup that her dream was "not that important." Relatedly, she said that the dream was not connected to her current waking life (it was "about a trip I had to the beach"). Thus, the dream seemed not to represent a current waking concern and so may have been difficult to work on.

\section{The Therapeutic Relationship}

After the session, Natalie gave the therapeutic relationship the highest possible rating (see Table 1 ). The therapist's rating, however, was lower than that of the larger sample, suggesting that the therapist questioned the relationship's strength. They were, however, able to work together in the session (i.e., no overt ruptures, completed all

Psychotherapy Research, Vol. 18, No. 2 (March 2008): pg. 200-215. DOI. This article is (c) Taylor \& Francis (Routledge) and permission has been granted for this version to appear in e-Publications@ Marquette. Taylor \& Francis (Routledge) does not grant permission for this article to be further copied/distributed or hosted elsewhere without the express permission from Taylor \& Francis (Routledge). 
three stages), and though she later expressed discomfort for having done so, Natalie did feel safe enough to cry.

We observed that the relationship remained on a superficial level, which impeded exploration of emotionally laden parts of Natalie's dream. There was little evidence of warmth, camaraderie (e.g., no humor, no light or casual conversation, little seemed smooth), or much of a bond. We wondered whether the therapist's acknowledged difficulty identifying with Natalie because of her race, hairstyle, and religiosity (see later Countertransference section) impaired her ability to bond with Natalie. In the absence of this bond, both may have hesitated to explore the meanings of Natalie's dream. We suspect, then, that the psychotherapy relationship impeded the acquisition of insight.

\section{Client Factors}

Attitudes toward dreams. Natalie's score was substantially lower than that of the larger sample (see Table I), indicating that she did not particularly value dreams.

Readiness/motivation. Presession, Natalie appeared ready and motivated to explore her dream. On a presession measure, she strongly agreed with the statement, "I am eager to learn more about what this particular dream means."

Client involvement. Natalie's ratings of involvement were comparable with the larger sample, but the therapist rated Natalie's involvement higher than did therapists in the larger sample, and trained judges rated Natalie's involvement lower than they did for clients in the larger sample (see Table I). We noted that, although Natalie generally complied with what the therapist asked throughout the session, she consistently refused the therapist's suggestions about seeking help at the counseling center. Our perceptions were that Natalie started the session relatively open and involved but then began to close down. Toward the end, there was minimal excitement in her voice, little enthusiasm, and a fair amount of resistance (see later discussion). 
NOT THE PUBLISHED VERSION; this is the author's final, peer-reviewed manuscript. The published version may be accessed by following the link in the citation at the bottom of the page.

Need for control. Natalie expressed repeated concern about what others thought of her, a concern that led to nausea. Much like her sense of herself as an hourglass in the dream that, to keep the line straight, required that she neither look up nor turn, Natalie seemed focused on not veering from a narrow and controlled path ("trying to control so I'll know what's going on"), one that led her to consider this dream as nothing more than a vague recollection of a childhood trip. Although this need to maintain the line in the dream seemed to reflect her literal desire to keep the "invisible straight line through the sand," it likely also reflected her figurative desire to maintain control over herself and her world. For example, she was angry about crying in the session and struggled to restrain her emotions. When she began to touch on less comfortable areas (her parents' divorce, her need to know what others thought of her), Natalie quit exploring.

Overwhelmed by affect. As noted, Natalie first cried when discussing her mother's hourglass and continued to cry periodically throughout the session. Such affective expression contradicts her statement that the dream was not affectively laden. Once Natalie began to cry, she seemed to invest tremendous energy in stopping such expression of emotion (see prior discussion). In addition, when she first cried while discussing her parents' divorce, Natalie was perplexed as to why she was crying, given that the divorce happened so long ago. She later admitted that she cried all the time. We surmise that her marked discomfort with intense emotional expression impeded her ability to examine the meanings of her dream and blocked her path toward insight. Furthermore, although she used affect-laden words (e.g., disgust, angry, fear, panic) to discuss dream images, she said that she had no feelings when asked to identify the affect associated with the images.

Interpersonal distrust and resistance. We noted the lack of other people in Natalie's dream, given that most dreams involve interpersonal content (see Hall \& Van de Castle, 1966). We cannot make inferences based only on one dream, but this absence did make us wonder whether Natalie may have difficulty trusting and opening up to others. She seemed to have been profoundly influenced by her parents' divorce and moving to another city. Hence, being in a dream session where she was encouraged to open up to a stranger may have

Psychotherapy Research, Vol. 18, No. 2 (March 2008): pg. 200-215. DOI. This article is (c) Taylor \& Francis (Routledge) and permission has been granted for this version to appear in e-Publications@Marquette. Taylor \& Francis (Routledge) does not grant permission for this article to be further copied/distributed or hosted elsewhere without the express permission from Taylor \& Francis (Routledge). 
been difficult, despite her stated desire to understand her dream. Natalie also seemed resistant during the session. She refuted the potential meaning of what appeared to be a meaning-laden dream, asserting that its content reflected simply her recollection of a trip to the beach. Furthermore, when the therapist suggested that Natalie might benefit from services at her university counseling center, Natalie declined these suggestions.

Lack of psychological mindedness. Natalie did not seem very psychologically minded. In fact, when she or her therapist discussed content that might lead to introspection (e.g., why Natalie wouldn't want to look up when limited to a boxed-in view, why she cried, why she would "mess up" the straight line, why she cared so much about what others think), Natalie's typical response was that she didn't know. Thus, rather than wrestle with what may lie beneath such content or questions, Natalie essentially closed the door on further exploration.

External distractions. Natalie seemed distracted during the session. She stated, for example, that she was in a rush because her father was picking her up halfway through the session (although she stayed for the whole session). In addition, she seemed distracted when her cell phone rang a few times in the latter part of the session.

\section{Therapist Factors}

Adherence and competence. The therapist conducted the steps in a gentle and supportive manner but remained at a superficial level and failed to follow the model's intent of deep exploration. Our sense was that the therapist was cautious with Natalie and thus missed opportunities to foster insight. As an illustration, the therapist failed to pursue Natalie's affect: When Natalie cried, the therapist's response was to normalize such crying rather than encourage exploration of why she was crying and how such affect might connect with her dream. The therapist also explored neither the potentially fruitful topics of Natalie's description of a childhood babysitter appearing "nice" to Natalie's parents but "mean to [Natalie and her sister]," the meaning of Natalie's feeling sick, nor what was happening in Natalie's life when this recurrent dream reappeared 3 years before the session. Finally, at 
one point when Natalie indicated that the dream might represent her desire to keep her family together, the therapist did not pursue that line of thinking.

In contrast to our perceptions, Natalie and her therapist rated the therapist as very competent, and the judges rated the therapist as about average (see Table I). Perhaps Natalie was grateful that the therapist did not challenge her, or perhaps Natalie felt comforted during the action stage by the role of religion and spirituality in her life. The therapist's self-ratings may likewise have reflected the gentleness with which she approached the session and her attempt to create a safe place for a client who was obviously uncomfortable.

Countertransference. The therapist acknowledged, on a postsession measure, that she initially feared she would have difficulty identifying with Natalie because of her race and hairstyle. The therapist also stated that she had to "work hard to respect" Natalie's turning to religion to address the concerns raised in the session. Moreover, the therapist rated her own unresolved needs, conflicts, or feelings as being "somewhat" evoked by the client (e.g., the therapist identified with Natalie's worrying about what others think and with the feeling that she takes on "so much responsibility"). Such countertransference may have made the therapist anxious about exploring the data in Natalie's dream. Furthermore, such anxiety may have prevented the therapist from noticing Natalie's discomfort with pursuing counseling or impelled the therapist to give her own values (i.e., counseling) greater worth than the client's preferences (i.e., not to pursue counseling but instead rely on religion to address her concerns).

Therapist skills. Probes for insight were associated with client insight in the immediate subsequent client speaking turn. One example came toward the end of the session. Here, Natalie acknowledged how burdensome her worrying had become and also how panicked she became when someone she loved was late. The therapist then asked, "How do you see that coming into play in the dream?" Natalie replied that it perhaps reflected her desire to take control, "to keep a straight line. I like taking on responsibility because I don't trust other people to 
do it taking in others' feelings and trying to control it so I'll know what's going on. I have to know what's going on."

Reflections of feeling (used five times) also were associated with immediate client insight. One example came in the exploration stage. Natalie explained that when her parents divorced, she moved from an all-White to an all-Black school, where she was teased for talking "White." She was angry with her mother for forcing her to move and afraid to make the "horrible" transition to the new school. The therapist responded, "Yeah, it sounds like an overarching misery." Natalie acknowledged, "Yes, right, it was. And I didn't like being there at all."

Natalie's therapist used three interpretations, with one associated with immediate client insight. In summarizing the insight stage, the therapist said, "So we have all these images and now we have a bunch of things that you think it might relate to. It does sound like there's a lot of parts in this that you enjoyed, like the beach and the hourglass and thinking about the game. I wonder if it might be, it seems like it's displaying some various feelings that you had at the time." Natalie replied, "Yeah I worry a lot I think that might have to do with the things that I go through I'm always concerned about what other people think of me. And it's really tough And it's my fault 'cause I take on responsibility when I don't have to. So, I could just think that instead of looking at the hourglasses I just think it represents more emotion than it does actual physical properties, like the hourglass or the sand. So, probably it's a frustration, happiness, and controlled."

\section{Summary of Insight Not Achieved Case}

Natalie's dream salience was moderate, but there was no apparent link (or no link was made) between the dream and her current waking life. Without such a link, her desire to reach new understanding may have been limited. The superficial and guarded relationship may have further decreased Natalie's willingness to explore her dream. Natalie seemed to minimally value dreams, became less involved and more resistant as the session progressed, evinced a need for control, was overwhelmed by affect, appeared

Psychotherapy Research, Vol. 18, No. 2 (March 2008): pg. 200-215. DOI. This article is (C) Taylor \& Francis (Routledge) and permission has been granted for this version to appear in e-Publications@Marquette. Taylor \& Francis (Routledge) does not grant permission for this article to be further copied/distributed or hosted elsewhere without the express permission from Taylor \& Francis (Routledge). 
reluctant to trust the safety of disclosing to a relative stranger, and was not particularly psychologically minded.

Entering into this mix also was Natalie's therapist, who was inexperienced and unable to break through Natalie's defenses. A more experienced clinician may have been able to nurture greater insight with Natalie. We wonder whether Natalie's therapist was aware of how guarded Natalie became during the session. In only one place did she ask about Natalie's in-session affect, and then she did not pursue Natalie's response. We noted multiple unrealized opportunities where the therapist could have probed or reflected what Natalie was feeling and pursued how those feelings related to the dream. Perhaps the therapist was frightened by Natalie's distress and sought to protect herself (therapist) and avert further arousal, or perhaps the therapist did not trust their relationship enough to pursue more arousal. Although such avoidance may or may not have lessened Natalie's affect (we cannot know how Natalie would have responded had the therapist been less protective), it may have derailed them from examining avenues of insight. Whatever the explanation, the therapist was limited in her ability to foster insight.

In addition, the therapist questioned her capacity to identify with Natalie because of her race and stated that she "had to work hard to respect" Natalie's religious beliefs, leading us to wonder about the possible effect of cultural differences. Perhaps the therapist was unable to monitor her countertransferential reactions and be fully aware of and present with Natalie's distress. Without such monitoring, the therapist's ability to soften Natalie's guardedness was likely impaired.

When moments of potential insight occurred in the session, both therapist and client fled from the exploration that may have led to insight. For both, it may have been too dangerous: Natalie was already distressed, seeking mightily to maintain emotional control, and perhaps unwilling to probe areas that could intensify her emotions; her inexperienced therapist may have been alarmed by Natalie's arousal, and thus kept the session on a superficial, and presumably safer, level. Hence, the dream, the relationship, client factors, therapist factors, and the interaction between the client and therapist all seemed to impede insight development.

Psychotherapy Research, Vol. 18, No. 2 (March 2008): pg. 200-215. DOI. This article is (c) Taylor \& Francis (Routledge) and permission has been granted for this version to appear in e-Publications@Marquette. Taylor \& Francis (Routledge) does not grant permission for this article to be further copied/distributed or hosted elsewhere without the express permission from Taylor \& Francis (Routledge). 
Although fewer, there were some facilitating factors. The dream was a moderately salient, troubling recurrent dream, and Natalie viewed the therapeutic relationship positively. She also initially seemed ready and motivated. Finally, the therapist was regarded as highly competent by the client and used skills associated with insight in the moment. Unfortunately, however, inhibiting factors outweighed facilitating factors such that the client did not gain insight.

\section{Discussion}

We now review the facilitating and inhibiting factors associated with insight attainment for these two single-session cases in conjunction with the earlier Hill et al. (2007) single-session case. We acknowledge, however, that we cannot make generalizations based on only three cases and offer the following as theoretical proposals or hypotheses.

\section{Factors Related to Insight}

\section{The Dream}

It appears that clients need at least a moderately salient dream that can be linked to waking life. More salient dreams may lead to more arousal, a state important for both dream sessions and psychotherapy (Hill, 2004b; Teyber, 2006). Interestingly, two of the three cases (Ingrid, Natalie) involved recurrent dreams from childhood and adolescence, which was typical of the larger sample from which these cases were drawn. Perhaps greater salience accompanies recurring dreams.

\section{The Therapy Relationship}

In two of the cases, the relationship appeared to set the stage for insight acquisition, although it did not seem to directly facilitate insight. Without a bond between client and therapist, insight acquisition may be more difficult. As is true of psychotherapy more generally (e.g., Luborsky, Crits-Christoph, Mintz, \& Auerbach, 1988; Orlinsky \& Howard, 1986), the relationship may form a foundation on which the work (i.e., insight) may be built. However, in the third case, 
in which insight declined, the relationship had a less clear role, because the therapist rated it low and the client rated it high. They thus appeared to experience the relationship distinctly, which may have affected the acquisition of insight (e.g., the therapist's not pursuing fruitful avenues because she sensed that a tenuous relationship may have reduced the likelihood that Natalie would achieve insight).

\section{Client Factors}

On the basis of our observations, we suggest that clients need at least moderately positive attitudes toward dreams for insight to develop. Indeed, it is hard to imagine that those who question the value of dreams would gain much insight from a dream session, unless they became convinced of the value of dreams during dream work.

Similar to observations from previous dream studies (see Hill \& Goates, 2004), psychological mindedness did not seem to be a prerequisite for achieving insight (Ingrid gained insight but did not appear strongly psychologically minded), but its lack may have impeded insight (as was the case with Shari and Natalie).

Furthermore, readiness for dream work and motivation throughout the session did appear to facilitate insight.

In addition, overwhelming client affect may derail insight development. Perhaps there is a tipping point beyond which insight development is impeded (if the client is too aroused, he or she may not be able to reach a new understanding). In addition, we noted a number of distracters (e.g., giggling, contradictions, uncertainty) that seemed to impede progress.

\section{Therapist Factors}

The two therapists in the successful cases were fairly competent with the dream model, whereas the therapist in the unsuccessful case had difficulty implementing the model (e.g., failed to explore paths related to client affect, became too directive in the action stage). Thus, at least minimal competence with the model seems necessary for insight development. 
In addition, it appears that some benign countertransference does not adversely affect, and may even facilitate, dream sessions. In contrast, extreme countertransference (e.g., anxiety about the client's level of disturbance; difficulty with the client's race, hairstyle, religiosity) may be debilitating. Clients' acquisition of insight, then, may be impeded when therapists have strong countertransference that they are unable to manage (Gelso \& Hayes, 1998; Hayes et al., 1998).

\section{Therapist Skills}

Probes for insight seemed helpful for facilitating immediate insight in all three cases. Such interventions possess an inherent demand characteristic, in that they specifically encourage or request clients to talk about insight. Past research (Hill \& Gormally, 1977; Hill, Rochlen, Zack, McCready, \& Dematatis, 2003) has also found probes beneficial for facilitating insight.

The helpfulness of other therapist interventions depended on the client. Interpretations were helpful with two clients (one successful and the unsuccessful case), although it appeared that it was both the interpretation and the client's immediate readiness for and response to the interpretation that fostered insight. Reflections of feelings facilitated insight for two clients (one successful and the other unsuccessful) but not for the third. Perhaps these two clients benefited from more affective support than did the other as they sought insight into their dreams.

\section{Application of Observations to Model of Insight Attainment}

Hill, Castonguay, et al. (2007) suggested that clients' acquisition of insight depends on therapists (a) establishing a therapy alliance; (b) preparing clients for insight by reducing their defenses, educating them about insight, and encouraging exploration of puzzling memories or stories; (c) looking for markers of client readiness for insight; (d) promoting insight with interventions that directly facilitate client insight (e.g., probes for insight, interpretations) or that help clients change behaviors, which in turn facilitates insight (e.g., behavioral assignments); and (e) helping clients consolidate insight via

Psychotherapy Research, Vol. 18, No. 2 (March 2008): pg. 200-215. DOI. This article is (c) Taylor \& Francis (Routledge) and permission has been granted for this version to appear in e-Publications@Marquette. Taylor \& Francis (Routledge) does not grant permission for this article to be further copied/distributed or hosted elsewhere without the express permission from Taylor \& Francis (Routledge). 
reinforcement, having clients articulate the insight in a memorable form, or repeating the insight in different ways to enable generalization.

Many elements of the proposed model fit our observations of these three cases, although they do so in a slightly different order. Likely because all three clients had only a single session and did not explore their dreams within ongoing therapy, each entered the process not with the establishment of a solid therapy alliance (Step a) or with preparation for insight (Step b) but rather because of a curiosity to understand her dream (Step c). In addition, as noted earlier, the dream needed to be salient (i.e., provocative, troubling, puzzling). In response to this marker, and because they were following Hill's integrative model of dream work, the therapists used interventions to promote client insight (Step d). These interventions indeed facilitated insight. In addition, they likely also facilitated the therapy relationship (Step a); in the absence of such facilitation, however, the relationship remained tenuous, as with Natalie (Step a). From our data, it also appears that client involvement complements therapist interventions in insight attainment. The therapists attended to insight consolidation as well (Step e). For example, at the end of the exploration and insight stages, they asked clients to summarize the insight gained, and they asked in the action stage what clients wished to do differently based on these insights. This step seemed effective for Shari and Ingrid but was not effective with Natalie, perhaps because she did not achieve enough insight to enable consolidation. Thus, the sequence of insight attainment began here with the presentation of a salient marker; was followed by therapist interventions to promote insight, in conjunction with client involvement in the process and building of the therapy relationship; and ended with insight consolidation.

\section{Limitations}

These observations must be viewed in their appropriate context: They derive from single sessions of dream work with college-age female volunteer clients and may be unique to these individuals. Our clients being volunteers may have introduced artificiality into the setting and interaction. Male clients, as well as those of different ages and from different (i.e., noncollege) settings, may have different 
experiences with respect to insight gains in dream work. In addition, the clients, therapists, researchers, and auditors were all women, and we do not know to what extent a male perspective might have altered the observations. Furthermore, all three therapists were still in training; it is possible that therapists with more clinical experience would have fostered insight differently. We also acknowledge that dreams may be difficult to describe, and thus our participants' ability to communicate about their dreams influenced our observations. Although we chose three clients who were similar in age, gender, and lack of previous or current therapy, the cases differed in other ways (e.g., client race, therapist familiarity with the model, therapist theoretical orientation).

In addition, our conclusions are affected by the extent to which we were able to counter our biases. We knew, for instance, which cases had attained insight and which had not, knowledge that might have influenced our analyses. To monitor such biases, we continually returned to the data to check our evidence, looked for disconfirming evidence, and audited each other's cases; however, observations need to be replicated. Finally, we are not able to draw causal inferences, given that we did not use an experimental design.

\section{Implications for Practice}

First, therapists should encourage clients to bring salient dreams into psychotherapy because such dreams appear to stimulate therapeutic progress. Second, clinicians may find it useful to assess client factors that appear related to insight development (e.g., attitudes toward dreams, readiness/motivation, involvement, defensiveness, affective arousal) both before and during the dream session. These variables may provide clues about whether clients will be receptive to working with dreams and may also alert therapists about areas of difficulty to be addressed within the dream work. Third, therapists should not expect clients to have sudden, epiphany-like, "aha" experiences about what their dreams mean. Likewise, they rarely uncover the interpretation (if such an interpretation exists); rather, dream work may enhance clients' understanding and then encourages them to continue to reflect on the meaning of the dreams.

Psychotherapy Research, Vol. 18, No. 2 (March 2008): pg. 200-215. DOI. This article is (c) Taylor \& Francis (Routledge) and permission has been granted for this version to appear in e-Publications@Marquette. Taylor \& Francis (Routledge) does not grant permission for this article to be further copied/distributed or hosted elsewhere without the express permission from Taylor \& Francis (Routledge). 
Finally, although this study focused explicitly on insight development via dream work, the observations may also have relevance for psychotherapy more broadly. For example, it may have been less important to these clients that the stimulus for the session was specifically a dream than that they were discussing something that evoked a sense of puzzlement and emotional salience. Thus, we might expect similar results when clients examine provocative memories or experiences. Similarly, observations related to the importance of the therapy relationship, clients' positive attitudes toward the therapy process as well as their readiness and motivation, and therapists' ability to follow and implement their model of therapy, their management of benign countertransference, and their use of specific skills all seem relevant to clients' ability to acquire insight in non-dream-based therapy. Likewise, when clients are overwhelmed by affect or when therapists have difficulty implementing their therapy model or managing strong countertransference, client insight in regular therapy may be impeded.

\section{Implications for Research}

We encourage other researchers to continue this case study approach, examining other cases to determine whether the same or different factors are implicated. It would also be interesting to explore how insight develops in large-sample studies, allowing for triangulation of observations with the case study approach. In addition, studying insight development in regular psychotherapy would help assess similarities and differences from dream work.

We remain curious about the influence of interpretations and reflections of feeling on insight attainment. Our investigations have offered evidence of their potential for fostering insight, but their role was less clear than that of probes for insight. For example, what is it about interpretations that may provoke client elaboration? Perhaps interpretations have different levels of depth (e.g., superficial vs. deep) and may then differentially affect clients. In addition, might interpretations be more helpful in longer term dream work, in which therapists know more about their clients? Similarly, perhaps reflections of feeling lead to insight when the reflection is deeper or introduces something new to the client.

Psychotherapy Research, Vol. 18, No. 2 (March 2008): pg. 200-215. DOI. This article is (c) Taylor \& Francis (Routledge) and permission has been granted for this version to appear in e-Publications@ Marquette. Taylor \& Francis (Routledge) does not grant permission for this article to be further copied/distributed or hosted elsewhere without the express permission from Taylor \& Francis (Routledge). 
NOT THE PUBLISHED VERSION; this is the author's final, peer-reviewed manuscript. The published version may be accessed by following the link in the citation at the bottom of the page.

\section{Acknowledgements}

- We thank the therapists and clients for their participation in this study as well as Jenna Behrens, Stacey Kleinman, and Jessica Thull for transcribing the sessions. We also thank Alan W. Burkard, Charles J. Gelso, and Lewis Z. Schlosser for reviewing earlier versions of this article.

\section{References}

Battle, C. G., Imber, S. D., Hoehn-Saric, R., Stone, A. R., Nash, E. R., \& Frank, J. D. (1966). Target complaints as criterion of improvement. American Journal of Psychotherapy, 20, 184-192.

Bohart, A. C. (2006). Insight and the active client. In L. G. Castonguay \& C. E. Hill (Eds), Insight in psychotherapy (pp. 257-277). Washington, DC: American Psychological Association.

Castonguay, L. G., \& Hill, C. E. (Eds). (2007). Insight in psychotherapy. Washington, DC: American Psychological Association.

Eudell-Simmons, E. M., \& Hilsenroth, M. J. (2005). A review of empirical research supporting four conceptual uses of dreams in psychotherapy. Clinical Psychology Psychotherapy, 12, 255-269.

Frank, J. D., \& Frank, J. B. (1991). Persuasion and healing: A comparative study of psychotherapy (3rd ed). Baltimore, MD: Johns Hopkins University Press.

Gelso, C. J., \& Hayes, J. (1998). The psychotherapy relationship: Theory, research, and practice. New York: Wiley.

Hall, C. S., \& Van de Castle, R. L. (1966). The content analysis of dreams. New York: Appleton-Century-Crofts.

Hayes, J. A., McCracken, J. E., McClanahan, M. K., Hill, C. E., Harp, J. S., \& Carozzoni, P. (1998). Therapist perspectives on countertransference: Qualitative data in search of a theory. Journal of Counseling Psychology, 45, 468-482.

Heppner, P. P., Kivlighan, D. M., \& Wampold, B. E. (1999). Research design in counseling (2nd ed). Pacific Grove, CA: Brooks/Cole.

Hill, C. E. (1996). Working with dreams in psychotherapy. New York: Guilford Press.

Hill, C. E. (Ed.). (2004a). Dream work in therapy: Facilitating exploration, insight, and action. Washington, DC: American Psychological Association.

Hill, C. E. (2004b). Helping skills: Facilitating exploration, insight, and action (2nd ed). Washington, DC: American Psychological Association.

Hill, C. E., Castonguay, L. G., Elliott, R., Gelso, C. J., Goldfried, M. R., Stiles, W. B., et al. (2007). Insight in psychotherapy: Definitions, processes,

Psychotherapy Research, Vol. 18, No. 2 (March 2008): pg. 200-215. DOI. This article is (c) Taylor \& Francis (Routledge) and permission has been granted for this version to appear in e-Publications@Marquette. Taylor \& Francis (Routledge) does not grant permission for this article to be further copied/distributed or hosted elsewhere without the express permission from Taylor \& Francis (Routledge). 
NOT THE PUBLISHED VERSION; this is the author's final, peer-reviewed manuscript. The published version may be accessed by following the link in the citation at the bottom of the page.

consequences, and research directions. In L. G. Castonguay \& C. E. Hill (Eds), Insight in psychotherapy (pp. 441-454). Washington, DC: American Psychological Association.

Hill, C. E., Corbett, M. M., Kanitz, B., Rios, P., Lightsey, R., \& Gomez, M. (1992). Client behavior in counseling and therapy sessions: Development of a pantheoretical measure. Journal of Counseling Psychology, 39, 539-549.

Hill, C. E., Crook, R., Hess, S. A., Goates-Jones, M., Roffman, M., Stahl, J., et al. (2006). Prediction of the session process and outcome in the Hill dream model: Contributions of client characteristics and the process of the three stages. Dreaming, 16, 159-185.

Hill, C. E., \& Goates, M. K. (2004). Research on the Hill cognitive-experiential dream model. In C. E. Hill (Ed.), Dream work in therapy: Facilitating exploration, insight, and action (pp. 245-288). Washington, DC: American Psychological Association.

Hill, C. E., \& Gormally, J. (1977). Effect of reflection, restatement, probe, and nonverbal behavior on client affect. Journal of Counseling Psychology, 24, 92-97.

Hill, C. E., \& Kellems, I. S. (2002). Development and use of the Helping Skills Measure to assess client perceptions of the effects of training and of helping skills in sessions. Journal of Counseling Psychology, 49, 264272.

Hill, C. E., Kelley, F. A., Davis, T. L., Crook, R. E., Maldonado, L. E., Turkson, M. A., et al. (2001). Predictors of outcome of dream interpretation sessions: Volunteer client characteristics, dream characteristics, and type of interpretation. Dreaming, 11, 53-72.

Hill, C. E., \& Knox, S. (2007). Facilitating insight in counseling and psychotherapy. In S. Brown \& R. W. Lent (Eds), Handbook of counseling psychology (4th ed). New York: Wiley.

Hill, C. E., Knox, S., Hess, S. A., Crook-Lyon, R., Goates-Jones, M., \& Sim, W. (2007). The attainment of insight in the Hill dream model: A case study. In L. G. Castonguay \& C. E. Hill (Eds), Insight in psychotherapy (pp. 207-230). Washington, DC: American Psychological Association.

Hill, C. E., Rochlen, A. B., Zack, J. S., McCready, T., \& Dematatis, A. (2003). Working with dreams using the Hill cognitive-experiential model: $A$ comparison of computer-assisted, therapist empathy, and therapist empathy + input conditions. Journal of Counseling Psychology, 50, 211-220.

Hill, C. E., Tien, H.-L., Shen, H.-B., Sim, W., Ma, Y., Choi, K.-H., \& Tashiro, T. (In press). Predictors of outcome of dream work for East Asian volunteer clients: Dream factors, anxious attachment, Asian values, and therapist input. Dreaming.

Psychotherapy Research, Vol. 18, No. 2 (March 2008): pg. 200-215. DOI. This article is (c) Taylor \& Francis (Routledge) and permission has been granted for this version to appear in e-Publications@Marquette. Taylor \& Francis (Routledge) does not grant permission for this article to be further copied/distributed or hosted elsewhere without the express permission from Taylor \& Francis (Routledge). 
NOT THE PUBLISHED VERSION; this is the author's final, peer-reviewed manuscript. The published version may be accessed by following the link in the citation at the bottom of the page.

Hilliard, R. B. (1993). Single-case methodology in psychotherapy process and outcome research. Journal of Consulting and Clinical Psychology, 61, 373-380.

Holtforth, M. G., Castonguay, L. G., Boswell, J. F., Angtuaco, L. A., Kakouros, A. A., \& Borkovec, T. D. (2006). Insight in cognitive-behavioral therapy. In L. G. Castonguay \& C. E. Hill (Eds), Insight in psychotherapy (pp. 57-80). Washington, DC: American Psychological Press.

Kazdin, A. E. (1981). Drawing valid inferences from case studies. Journal of Consulting and Clinical Psychology, 49, 183-192.

Luborsky, L., Crits-Christoph, P., Mintz, P., \& Auerbach, A. (1988). Who benefits from psychotherapy? Predicting therapeutic outcomes. New York: Basic Books.

Messer, S. B., \& McWilliams, N. (2006). Insight in psychodynamic therapy: Theory and assessment. In L. G. Castonguay \& C. E. Hill (Eds), Insight in psychotherapy (pp. 9-29). Washington, DC: American Psychological Association.

Orlinsky, D. E., \& Howard, K. I. (1986). The psychological interor of psychotherapy: Explorations with the Therapy Session Reports. In L. S. Greenbery \& W. M. Pinsof (Eds.), The psychotherapeutic process: A research handbook (pp. 477-501). New York: Guilford Press.

Pascual-Leone, A., \& Greenberg, L. S. (2006). Insight and awareness in experiential therapy. In L. G. Castonguay \& C. E. Hill (Eds), Insight in psychotherapy (pp. 31-56). Washington, DC: American Psychological Association.

Pesant, N., \& Zadra, A. (2004). Working with dreams in therapy: What do we know and what should we do? Clinical Psychology Review, 24, 489512.

Stiles, W. B. (2003). When is a case study scientific research? Psychotherapy Bulletin, 38, 6-11.

Stiles, W. B. (2005). Case studies. In J. C. Norcross, L. E. Beutler \& R. F. Levant (Eds), Evidence-based practices in mental health: Debate and dialogue on the fundamental questions (pp. $\mathrm{xxx}-\mathrm{xxx}$ ). Washington, DC: American Psychological Association.

Teyber, E. (2006). Interpersonal process in psychotherapy: An integrative model (5th ed). Belmont, CA: Brooks/Cole.

Wonnell, T., \& Hill, C. E. (2000). The effects of including the action stage in dream interpretation. Journal of Counseling Psychology, 47, 372-379.

Yin, R. K. (1994). Case study research: Design and methods (2nd ed). Thousand Oaks, CA: Sage.

Psychotherapy Research, Vol. 18, No. 2 (March 2008): pg. 200-215. DOI. This article is (c) Taylor \& Francis (Routledge) and permission has been granted for this version to appear in e-Publications@Marquette. Taylor \& Francis (Routledge) does not grant permission for this article to be further copied/distributed or hosted elsewhere without the express permission from Taylor \& Francis (Routledge). 
NOT THE PUBLISHED VERSION; this is the author's final, peer-reviewed manuscript. The published version may be accessed by following the link in the citation at the bottom of the page.

\section{Notes}

- 1Department of Counseling and Educational Psychology, School of Education, Marquette University, 2Department of Psychology, University of Maryland, 3Department of Counseling and College Student Personnel, Shippensburg University, and 4Department of Counseling Psychology and Special Education, School of Education, Brigham Young University

- Correspondence: Sarah Knox, Department of Counseling and Educational Psychology, School of Education, Marquette University, Milwaukee, WI 53201-1881. E-mail: sarah.knox@marquette.edu 
NOT THE PUBLISHED VERSION; this is the author's final, peer-reviewed manuscript. The published version may be accessed by following the link in the citation at the bottom of the page.

\section{Appendix}

Table 1. Scores for the Three Cases Compared with Data from the Larger Sample

\begin{tabular}{|c|c|c|c|c|c|}
\hline \multirow{2}{*}{ Variable } & \multirow[b]{2}{*}{$\begin{array}{l}\text { Case 1: } \\
\text { (Shari) }\end{array}$} & \multirow[b]{2}{*}{$\begin{array}{l}\text { Case 2: } \\
\text { (Ingrid) }\end{array}$} & \multirow[b]{2}{*}{$\begin{array}{l}\text { Case 3: } \\
\text { (Natalie) }\end{array}$} & \multicolumn{2}{|c|}{ Larger Sample } \\
\hline & & & & $M$ & $S D$ \\
\hline \multicolumn{6}{|l|}{ Judge-rated client insight } \\
\hline Initial & $5.33^{a}$ & $2.67^{\mathrm{d}}$ & 4.75 & 4.29 & 1.58 \\
\hline Postexploration stage & $6.67^{b}$ & $3.33^{\mathrm{c}}$ & 4.75 & 5.36 & 1.48 \\
\hline Postinsight stage & $8.00^{b}$ & 6.67 & $4.25^{d}$ & 5.99 & 1.59 \\
\hline Follow-up & $9.00^{b}$ & $8.00^{b}$ & $2.00^{d}$ & 6.21 & 1.93 \\
\hline \multicolumn{6}{|l|}{ Client dream } \\
\hline Salience & $3.60^{2 \pi}$ & 3.40 & 3.40 & 3.17 & 0.77 \\
\hline Attitudes & 3.78 & $4.55^{b}$ & $2.77^{d}$ & 3.74 & 0.66 \\
\hline \multicolumn{6}{|l|}{ Client involvement } \\
\hline Client rated & $9.00^{n}$ & $9.00^{8}$ & 8.67 & 8.35 & 0.98 \\
\hline Therapist rated & 7.00 & $6.33^{c}$ & $8.67^{b}$ & 6.99 & 1.24 \\
\hline Judge rated & $7.44^{b}$ & 6.44 & $5.42^{d}$ & 6.50 & 1.02 \\
\hline \multicolumn{6}{|l|}{ Therapist competence } \\
\hline Client rated & $9.00^{b}$ & $9.00^{b}$ & $9.00^{b}$ & 8.39 & 0.63 \\
\hline Therapist rated & 6.33 & $3.67^{\text {d }}$ & $7.33^{\mathrm{a}}$ & 6.56 & 1.34 \\
\hline Judge rated & $7.33^{6}$ & 6.00 & 5.58 & 6.02 & 1.19 \\
\hline \multicolumn{6}{|l|}{ Relationship Scale } \\
\hline Client rated & $5.00^{2}$ & $5.00^{2}$ & $5.00^{\mathrm{a}}$ & 4.57 & 0.61 \\
\hline Therapist rated & 4.25 & 4.00 & $3.75^{t}$ & 4.09 & 0.64 \\
\hline \multicolumn{6}{|l|}{ Session Evaluation Scale } \\
\hline Client rated & $5.00^{2}$ & $5.00^{\circ}$ & 4.50 & 4.57 & 0.68 \\
\hline Therapist rated & $4.50^{\mathrm{a}}$ & $3.75^{c}$ & $3.75^{\circ}$ & 4.10 & 0.67 \\
\hline \multicolumn{6}{|l|}{ Client target problem } \\
\hline Presession & 6 & 6 & 7 & 6.43 & 2.64 \\
\hline Postsession & 10 & $12^{b}$ & 9 & 9.85 & 2.17 \\
\hline Follow-up & $11^{a}$ & $11^{b}$ & $5^{d}$ & 9.13 & 2.09 \\
\hline
\end{tabular}

Note. $\mathrm{N}$ for the larger sample $=159$. Effect size $(E S)=($ sample mean - client's score)/sample SD. Insight (Hill et al., 1992) was rated by trained undergraduate judges for the Hill et al. (2006) study using 9-point scales $(9=$ high). Dream Salience (Hill et al., in press) and Attitude Toward Dreams (Hill et al., 2001) were completed by clients presession using 5 -point scales $(5=$ high). Client involvement (Wonnell \& Hill, 2000) and therapist competence (Hill et al., 2006) were rated using 9-point scales (9 $=$ high $)$ and are averaged across the exploration, insight, and action stages. Relationship Scale (Hill \& Kellems, 2002) and Session Evaluation Scale (Hill \& Kellems, 2002) used 5-point scales ( $5=$ high). Target Problem (modified from Battle et al., 1966 , identified by client after session) used a 13-point scale ( $1=$ worst possible functioning, 13 = best possible functioning).

aMedium ES higher than sample. bLarge ES higher than sample. cMedium ES lower than sample. 'Large ES lower than sample.

Psychotherapy Research, Vol. 18, No. 2 (March 2008): pg. 200-215. DOI. This article is @ Taylor \& Francis (Routledge) and permission has been granted for this version to appear in e-Publications@Marquette. Taylor \& Francis (Routledge) does not grant permission for this article to be further copied/distributed or hosted elsewhere without the express permission from Taylor \& Francis (Routledge). 